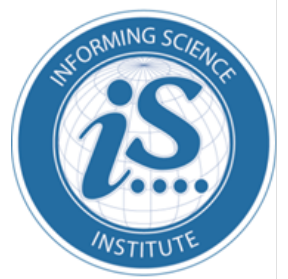

Proceedings of the Informing Science + Information Technology Education Conference

An Official Publication

of the Informing Science Institute

InformingScience.org

InformingScience.org/Publications

June 30 - July 4, 2019, Jerusalem, Israel

\title{
AN OVERVIEW OF THE GLOBAL OPEN EDUCATIONAL BADGE MOVEMENT: \\ OPPORTUNITIES AND CHALLENGES [ABSTRACT]
}

\author{
Terry M. McGovern \\ University of South Florida, \\ Tampa, FL, USA \\ mcgovernt@,mail.usf.edu
}

\begin{abstract}
Aim/Purpose

Educational stakeholders have little understanding of digital educational badging.

Background A current overview of the developing educational badging ecosystem, key terminology, advantages, challenges, and examples of badge utilization.

Methodology Illustrative case study

Contribution Creates a record of the developing digital badge industry providing insights to educational stakeholders.

Findings Highly dynamic industry, developing unique terminology, may improve access to higher education, reduce credential fraud, decrease concerns about vague transcripts, and support customized learning. The challenges include a crowded market with many providers, establishing standards, and determining the value proposition of the credential.
\end{abstract}

Recommendations for Practitioners

Recommendations for Researchers

Impact on Society
Before engaging in a long-term badging strategy, understand the badging system as well as the advantages and challenges of this innovation.

Consider the profound shift offered by the badging system and the relationship that digital educational badges have on grounded theory related to credentials such as human capital development theory, signaling theory, and credentialism theory.

Digital badging marks a paradigm shift in how we think about formal human development; from one that is institution-centric and bounded to one that is learner-centric and unbounded.

Accepting Editor: Eli Cohen | Received: January 15, 2019 | Revised: March 1, 2019 | Accepted: March 3, 2019.

Cite as: McGovern, T. M. (2019). An overview of the global open educational badge movement: Opportunities and challenges [Abstract]. Proceedings of the Informing Science and Information Technology Education Conference, Jerusalem, Israel, pp. 185-186. Santa Rosa, CA: Informing Science Institute. https://doi.org/10.28945/4242

(CC BY-NC 4.0) This article is licensed to you under a Creative Commons Attribution-NonCommercial 4.0 International License. When you copy and redistribute this paper in full or in part, you need to provide proper attribution to it to ensure that others can later locate this work (and to ensure that others do not accuse you of plagiarism). You may (and we encourage you to) adapt, remix, transform, and build upon the material for any non-commercial purposes. This license does not permit you to use this material for commercial purposes. 
Future Research

Keywords
As a new innovation, there is a wide range of needed research. Most current research involves motivational impacts on K-12 learners. Based on this investigation, research regarding impact on access, pedagogy, security, credential information granularity, case studies about choosing a badging platform, value proposition, and the development of standards is needed.

badges, open badges, badging, access to higher education, transcript ambiguity, credential-fraud, open pathways, badge challenges

\section{OVERVIEW}

Educational stakeholders have little understanding of digital educational badging. This exploratory case study provides a current overview of the developing global educational badging ecosystem, key terminology, advantages, challenges, and examples of badge utilization. It creates a record of the evolving digital badge credential providing insights to educational stakeholders. This emerging innovation may improve access to higher education, reduce credential fraud, decrease concerns about vague transcripts, and support customized learning. The challenges include tempering hype versus reality, establishing global standards in a dynamic environment, and creating awareness and buy-in of a global badging ecosystem. A primary goal of this study is to identify future research for this promising innovation.

\section{BIOGRAPHY}

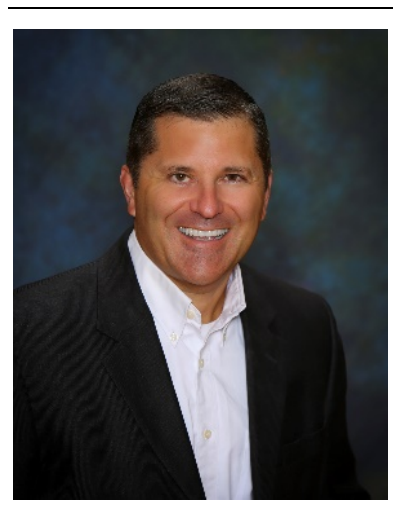

Terry McGovern received his Doctorate of Management from the University of Phoenix's School of Advanced Studies, his M.H.S. from Providence University and his M.S. from the Air Force Institute of Technology. He is a doctoral candidate in the University of South Florida's D.B.A. program with an expected graduation date of December, 2019. He is currently an Assistant Professor of Business Management at the University of Wisconsin-Parkside and the interim Program Manager of the University Learning Store, a digital badging consortium involving six major U.S. universities. Dr. McGovern's areas of expertise include strategy, pedagogy, operations, organizational behavior, and professional ethics. He is interested in case research and recently recognized by the North American Case Research Association's at its annual conference in October of 2017 for a case study he authored on succession planning. Dr. McGovern also has done consulting in the areas of strategic planning, leadership development, employee feedback systems, family business succession planning, and multi-generational workplaces. He is currently investigating educational digital badges. Dr. McGovern has authored numerous articles, presented in a wide range of settings including academic and industry conferences. His doctoral dissertation examined executive development in the United States Air Force. He has taught Operations Management, Professional Ethics, Strategic Planning, Organizational Behavior, Global Business, Project Management, and Leadership development courses at the graduate and undergraduate level, in various delivery formats, including face-to-face, blended, and online. Dr. McGovern served for 20 years as a U.S. Air Force officer in the areas of nuclear missile operations, satellite operations, and staff positions including flag-officer speech writer, faculty member, and director of an enterprise-level research cell while stationed in the Pentagon. 